\title{
A note on reported plant fossils from the Flume Ridge area of southwestern New Brunswick
}

\author{
L.R. Fyffe \\ New Brunswick Department of Natural Resources and Energy, Geological Surveys Branch, \\ P.O. Box 6000, Fredericton, New Brunswick E3B 5H1, Canada \\ and \\ R.F. Miller \\ The New Brunswick Museum, Natural Sciences Division, 277 Douglas Avenue, \\ Saint John, New Brunswick E2K 1E5, Canada \\ Date Received January 15, 1992 \\ Date Accepted March 6, 1992
}

\begin{abstract}
Reports of geological surveys undertaken during the latter part of the last century state that plant fragments were recovered from pre-Carboniferous rocks of the Flume Ridge area in Charlotte County, New Brunswick. An attempt was made to confirm the presence of these plant remains in order to provide age constraints on the otherwise unfossiliferous Digdeguash, Sand Brook, and Flume Ridge formations. Re-examination of a reported locality on Cox Brook and of an original specimen stored at the New Brunswick Museum in Saint John suggests that material identified as "Lepidostrobus" is actually a spotted slate chip incorporated in a wacke bed. The recognized inorganic nature of the supposed fossils precludes assignment of specific ages to the pre-Carboniferous rocks underlying a large tract of southwestern New Brunswick.
\end{abstract}

Les rapports des levés géologiques entrepris vers la fin du siècle dernier mentionnent que des fragments de plantes furent trouvés dans des roches pré-Carbonifère de la région de Flume Ridge du comté de Charlotte, NouveauBrunswick. Une tentative a été faite de confirmer la présence de ces restes de plantes afin de fournir des données sur l'âge des formations, par ailleurs non fossilifères, de Digdeguash, Sand Brook et Flume Ridge. Les réexamens d'un site mentionné le long du ruisseau Cox et d'un échantillon original conservé au Musée du Nouveau-Brunswick à SaintJean suggère que le matériel identifié comme "Lepidostrobus" est en fait un fragment de shale tacheté dans un lit de wacke. La nature inorganique reconnue des supposés fossile empêche l'attribution đ’âges spécifiques aux roches préCarbonifère sous-jacentes à une grande superficie du sud-est du Nouveau-Brunswick.

[Traduit par le joumal]

\section{INTRODUCTION}

Much of Charlotte County, New Brunswick, from the St. Croix River on the Maine border northeastward to Piskahegan Stream, is underlain by sedimentary rocks of uncertain age and stratigraphic position (Fig. 1). The establishment of a reliable stratigraphic succession and age for these pre-Carboniferous rocks has been hampered by their structural complexity and lack of fossils (Fyffe and Riva, 1990; Ludman, 1991). Fossil plants have been reported from this area in reports of surveys carried out in the nineteenth century (Bailey and Matthew, 1872) and would provide valuable age control if their presence could be confirmed. During a geological investigation of the Flume Ridge area (Fig. 1), one of the authors (LRF) was able to relocate a reported fossil site on Cox Brook. Evidence that the supposed fossils are actually of inorganic origin is presented below.

\section{STratigra Phy}

Regional geology maps (scale 1:63 360) that included the Flume Ridge area have been published by MacKenzie and Alcock (1960), and Ruitenberg (1967). The stratigraphy depicted in Figure 1 is based on this earlier work and on more detailed mapping (scale 1:20 000) by Fyffe (1991).

The Digdeguash Formation is comprised largely of medium grey, medium - to thick-bedded lithic wacke interstratified with dark grey slate. In order of abundance, the wackes contain angular quartz grains, feldspar, volcanic and granophyric fragments, and muscovite flakes set in a silty matrix comprising approximately $50 \%$ of the rock. Thick-bedded, light grey quartz wackes, which occur locally in the southern part of the area, contain single and polycrystalline grains of quartz set in a $15 \%$ silty matrix. The Sand Brook Formation comprises thick wacke beds that grade upward from a light 


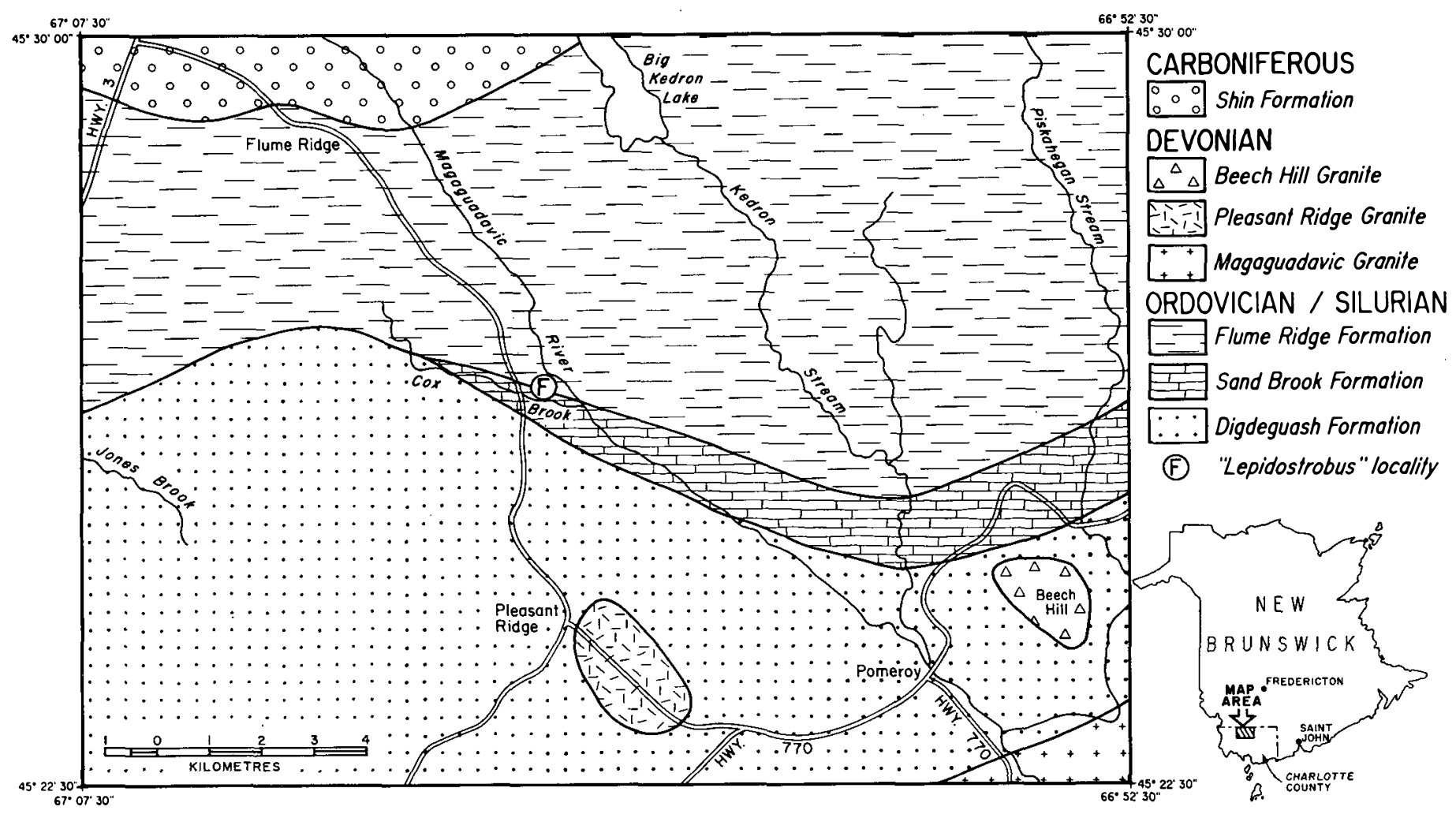

Fig. 1. Geology of the Flume Ridge area showing reported Cox Brook fossil site.

green feldspathic sandstone to a laminated green and maroon siltstone top. The abundance of epidote and actinolite, indicative of a calc-silicate composition, is responsible for the light green colour of the Sand Brook Formation in contrast to the grey colour of the Digdeguash Formation. The Sand Brook Formation thins by interfingering westward with dark grey slate of the Digdeguash Formation (Fig. 1). The Flume Ridge Formation typically comprises light grey, thin- to medium-bedded micaceous, calcareous wacke and siltstone interstratified with light to medium grey, calcareous and noncalcareous slate. Within a few metres of its contact with the underlying Sand Brook Formation, the Flume Ridge Formation contains alternating thin beds of calcareous and noncalcareous wacke. In the western part of the area, calcareous slates of the Flume Ridge Formation directly overlie wackes of the Digdeguash Formation (Fig. 1).

\section{Cox Brook Pseudofossils}

Bailey and Matthew (1872) reported the presence of Lepidodendron ${ }^{1}$ in pale grey argillite on Cox Brook toward the western end of Flume Ridge (Fig. 1). The discovery of plant fossils at this location was of considerable significance as they occurred at the contact between two major units then recognized in southwestern New Brunswick - the dark argillite group [Cookson and Digdeguash formations of Ruitenberg (1967)] and pale argillite group [Flume Ridge Formation of Ruitenberg (1967)]. The pale argillite group was consequently assigned to the Devonian based upon the Cox Brook fossils and supposed lithological similarity to the plant-bearing Little River Group of the Saint John area, which was at that time considered to be Late Devonian in age (Matthew, 1863; Bailey and Matthew, 1872; Bailey et al., 1877, 1880).

Matthew (1907) described one of the plant fragments from the Cox Brook locality and assigned it to Lepidostro$b_{u s}{ }^{2}$, noting that deformation had obscured details of the fossil. He also stated that it was unusual for this genus to occur in rocks that were considered on regional geological criteria to be as old as Silurian. Matthew (1910) reiterated his contention that the pale argillite group could be correlated with the Little River Group and concluded, therefore, that the

\footnotetext{
${ }^{1}$ The genus Lepidodendron is classified with the lycopods-a group of plants resembling present-day club-mosses. Lycopods possess branching stems covered with elongate evergreen leaves that produce a characteristic pattem of leaf scars. Lepidodendron trees were probably the most conspicuous life forms on the Carboniferous landscape, growing to heights of $40 \mathrm{~m}$ with trunks $2 \mathrm{~m}$ in diameter at the base (Taylor, 1981).
}

${ }^{2}$ Lepidostrobus is the generic designation for slender and cylindrical cones borne by Lepidodendron. The cones are typically 8 to $20 \mathrm{~cm}$ in length and consist of a central axis bearing sporophylls in either a spiral or whorled arrangement (Andrews, 1961). 
latter must be Silurian rather than Late Devonian in age. However, this correlation became untenable when Stopes (1914) conclusively documented the Carboniferous age of the Little River Group [Lancaster Formation of Alcock (1938)], whereas, the pale argillite group (Flume Ridge Formation) unconformably underlies Carboniferous strata (Fig. 1).

It is unlikely, from the above discussion, that Lepidodendron or Lepidostrobus, which are no older than Late Devonian (Andrews, 1961; Stewart, 1983), could actually occur within the probable Silurian Flume Ridge Formation. Therefore, during recent mapping of the Flume Ridge area (Fyffe, 1991), an attempt was made to locate and collect the Cox Brook site in order to determine the actual character of the reported fossil remains. The specimen illustrated by Matthew (1907) was also examined in the collections of the New Brunswick Museum.

Neither Bailey and Matthew (1872) nor Matthew (1907) give an exact location for their fossil find along the bank of Cox Brook. However, the best exposed section occurs at the falls about $400 \mathrm{~m}$ downstream from the bridge on the Flume Ridge Road (Fig. 1). Rocks exposed at the base of the falls are interbedded, light grey calcareous and noncalcareous wacke and siltstone and light to dark grey slates characteristic of the transition between the Sand Brook Formation and overlying Flume Ridge Formation (Fig. 2). Features observed just above the falls as spotted dark grey sheens on the weathered bedding surfaces of light grey calcareous wacke (Fig. 3) may be those described by Matthew (1907) as "fragments of long, straight, smooth stems" that were associated with the Lepidostrobus specimen. However, they actually represent very thin selvages of pelitic beds that display incipient porphyroblastic development of regional metamorphic chlorite.

An exposure of the Digdeguash Formation on the Digdeguash River, about $9 \mathrm{~km}$ southwest of Pleasant Ridge (outside the limits of the Flume Ridge area shown in Figure 1), contains structures similar in size, shape, and texture to Matthew's Lepidostrobus. The spotted dark grey fragment in the specimen from this site (Fig. 4) is clearly a slate chip incorporated in micaceous wacke.

The description of Lepidostrobus given by Matthew (1907) was based on a single specimen collected from Cox Brook in 1868. The specimen is in the Type Collection of the New Brunswick Museum (NBMG 8428). It measures $4.5 \mathrm{~cm}$ in length and is $1.5 \mathrm{~cm}$ wide and shows a sharp contact with the surrounding matrix (Fig. 5). Although the specimen demonstrates a superficial resemblance to Lepidostrobus, close examination reveals none of the characteristics of a cone. Its close resemblance to the specimen from the $\mathrm{Di}$ gdeguash River suggests that it represents a dark grey slate chip within calcareous wacke. The "scales" noted by Mat-

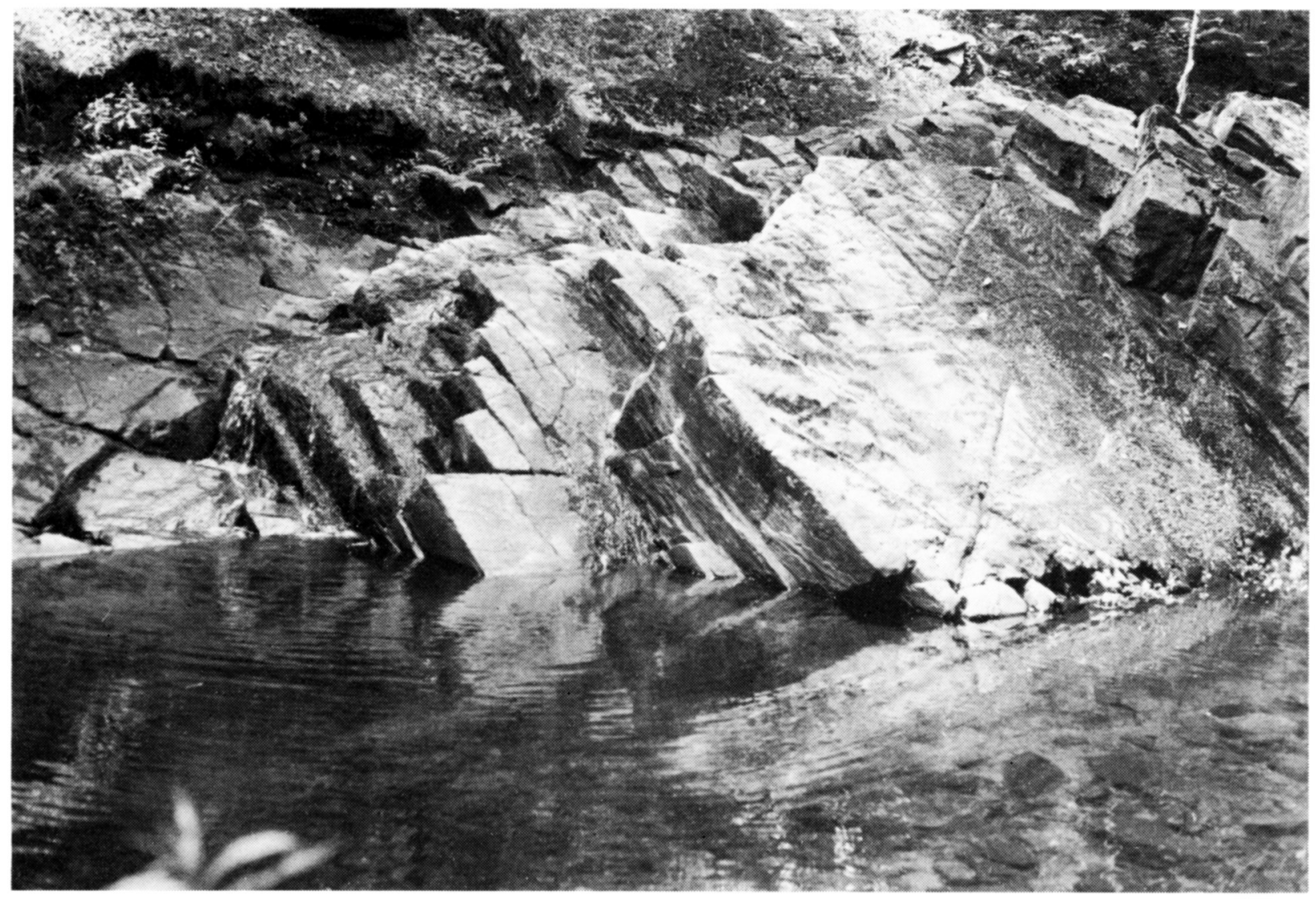

Fig. 2. Exposure of Flume Ridge Formation at the base of falls on Cox Brook. Beds are dipping to the northeast. The contact with the underlying $S$ and Brook Formation is placed at the base of the lowest calcareous bed. 


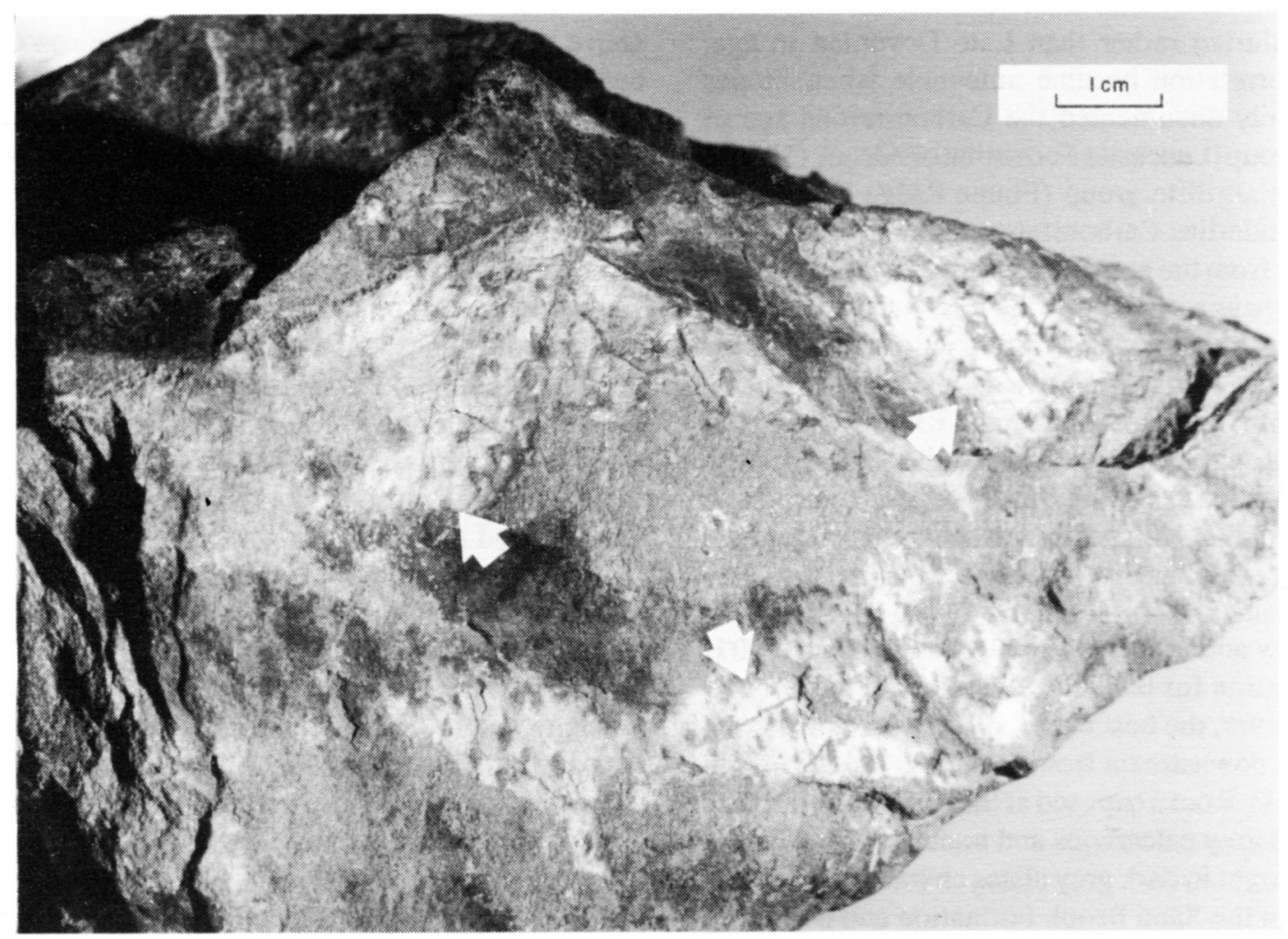

Fig. 3. Specimen of calcareous wacke from the Flume Ridge Formation just above falls on Cox Brook - NBMR 1085. Arrows point to spotted sheen, which may have been misidentified as plant remains.

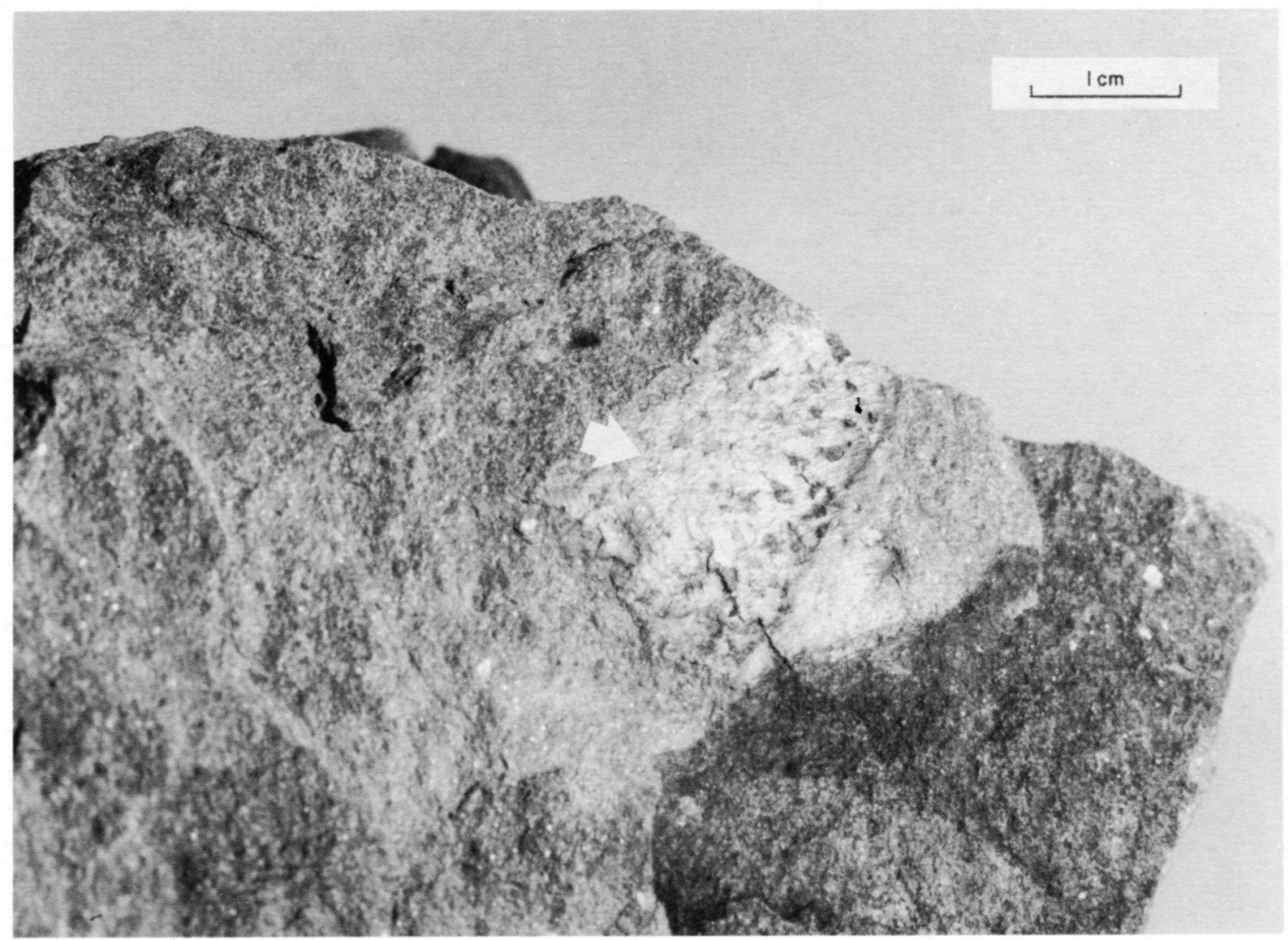

Fig. 4. Specimen of micaceous wacke from the Digdeguash Formation in the Digdeguash River - NBMR 1086. Arrow points to spotted slate chip. 


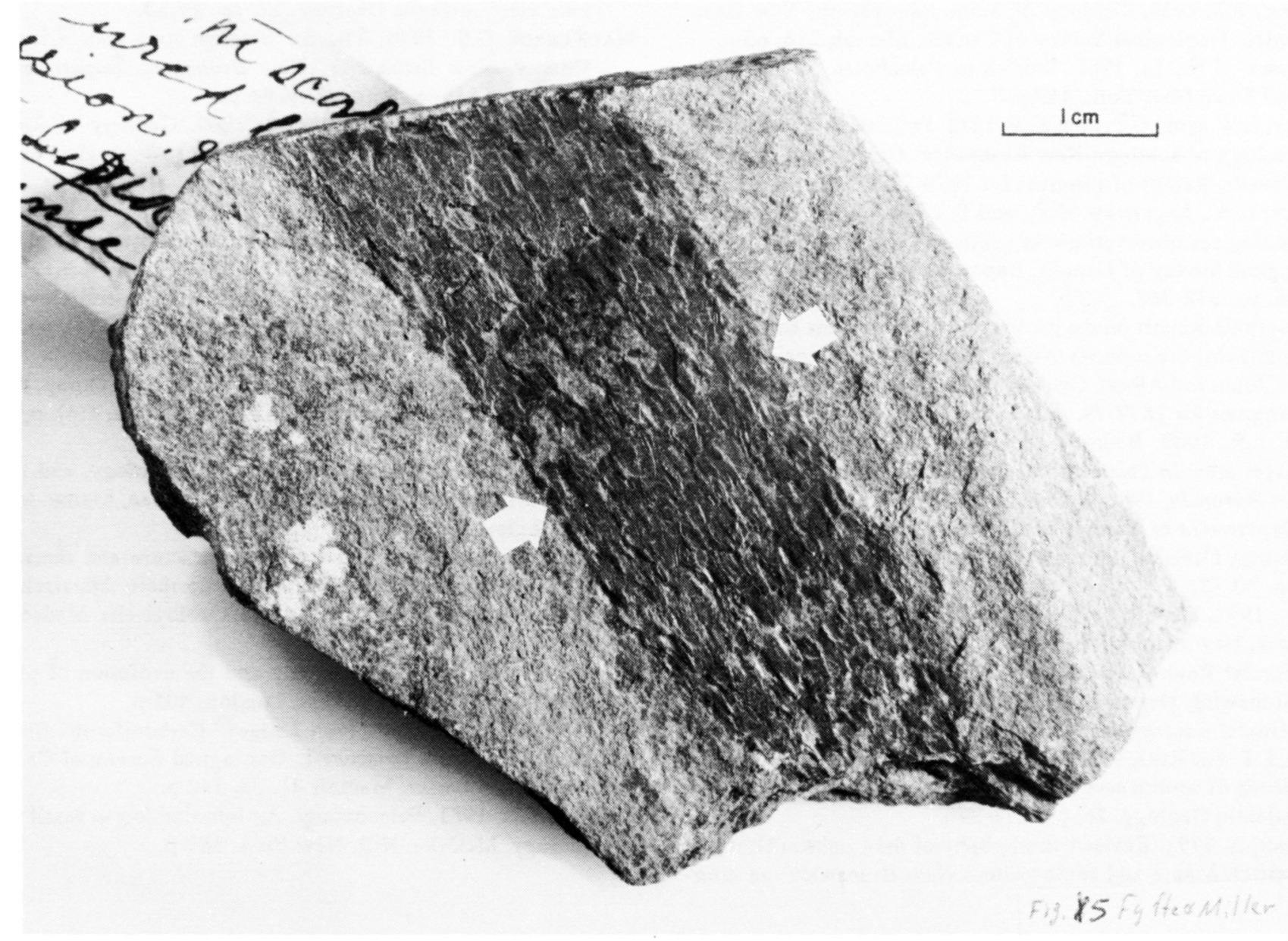

Fig. 5. Matthew's (1907) "Lepidostrobus" specimen - NBMG 8428 (between arrows).

thew (1907) as part of the structure of the cone are oval spots, probably of chlorite, developed parallel to the intersection of bedding and cleavage in the pelite.

\section{Conclusions}

The reported presence of plant fossils in the Flume Ridge Formation by Bailey and Matthews (1872) was noted by MacKenzie (1940) and Ruitenberg (1967), and likely influenced their stratigraphic interpretations of southwestern New Brunswick to some degree. However, it is now clear from the demonstrated inorganic nature of these supposed fossils that assignment of specific ages to the Digdeguash and Flume Ridge formations is unwarranted. It can only be surmised that this thick package of rocks is older than the unconformably overlying Carboniferous strata and is likely younger than the Ordovician (Tremadocian to Caradocian) Cookson Group (Fyffe and Riva, 1990), which apparently stratigraphically underlies it (Ludman, 1991).

Ruitenberg (1967) assigned a Late Silurian to Early Devonian age to the Flume Ridge Formation since it conformably overlies the Digdeguash Formation, which he interpreted to interdigitate eastward with strata correlated with the
Upper Silurian Waweig Formation. Fyffe (1991) was unable to lithologically distinguish between rocks of the Digdeguash Formation and those previously mapped as the Waweig Formation in the Flume Ridge area. He therefore recommended restricting the use of the term Waweig Formation to its type-area along Passamaquoddy Bay on the Bay of Fundy. This effectively negated evidence for considering the Flume Ridge Formation to be as young as Early Devonian. Other criteria suggest a Late Ordovician to Silurian age for the Flume Ridge Formation: (1) the Flume Ridge Formation appears to grade by reduction in carbonate content into graptolite-bearing Silurian (Wenlockian to Ludlovian) wackes of the Fredericton area (Fyffe, 1989); (2) primitive vascular plant remnants have been recovered from the Flume Ridge Formation just across the border in Maine (Ludman, personal communication, 1990); (3) calcareous rocks along strike in the Waterville-Vassalboro area of south-central Maine contain Silurian (late Llandoverian to Wenlockian) graptolites (Osberg, 1968). It can therefore be inferred from this evidence that the Ordovician-Silurian boundary occurs either near the base of the Flume Ridge Formation, or within the underlying Sand Brook or Digdeguash formations. 
Alcock, F.J. 1938. Geology of Saint John region, New Brunswick. Geological Survey of Canada, Memoir 216, 65 p.

ANDREws, H.N., JR. 1961. Studies in Paleobotany. John Wiley and Sons, New York, 487 p.

Bailey, L.W. and Matthew, G.F. 1872. Preliminary report on the geology of southern New Brunswick. Geological Survey of Canada, Report of Progress for 1870-71, Part 2, pp. 13-240.

Bailey, L.W., Matthew, G.F., and Ells, R.W. 1877. Report of geological observations in southern New Brunswick. Geological Survey of Canada, Report of Progress 1875-76, Part 16. pp. 348-368.

1880. Report on the geology of southern New Brunswick, embracing the counties of Charlotte, Sunbury, Queens, Kings, St. John, and Albert. Geological Survey of Canada, Report of Progress for 1878-79, Part D. pp. 1-26.

FyfFe, L.R. 1989. Bedrock geology of the McAdam-St. Croix River area. In Thirteenth Annual Review of Activities, Project Résumés, 1988. Edited by S.A. Abbott. New Brunswick Department of Natural Resources and Energy, Minerals and Energy Division, Information Circular 88-2, Second Edition, pp. 70-75.

1991. Geology of the Flume Ridge-Kedron Stream map area, New Brunswick. In Project Summaries for 1991, 16th Annual Review of Activities. Edited by S.A. Abbott. New Brunswick Department of Natural Resources and Energy, Mineral Resources, Information Circular 91-2, pp. 12-20.

FyFFe, L.R. and Riv A, J. 1990. Revised stratigraphy of the Cookson Group of southwestern New Brunswick and adjacent Maine. Atlantic Geology, 26, pp. 271-276.

Ludman, A. 1991. Revised stratigraphy of the Cookson Group in eastern Maine and southwestern New Brunswick: an alter- nate view. Atlantic Geology, 27, pp. 49-55.

MacKenzie, G.S. 1940. The St. Stephen map-area, Charlotte County, New Brunswick. New Brunswick Department of Lands and Mines, Paper 40-6, 46 p.

MacKenzie, G.S. and Alcock F.J. 1960. Geology of Rolling Dam, Charlotte County, New Brunswick. Geological Survey of Canada, Map 1096A.

MatThew, G.F. 1863. Observations on the geology of Saint John County, New Brunswick. Canadian Naturalist and Geologist, 8. pp. 241-260.

1907. On some new species of Silurian and Devonian plants. Royal Society of Canada, Transactions, 1(4), pp. 185197.

1910. The geological age of the Little River Group. Royal Society of Canada, Transactions, Third Series, 3(4), pp. $67-$ 75.

OsBerg, P.H. 1968. Stratigraphy, structural geology, and metamorphism of the Waterville-Vassalboro area, Maine. Maine Geological Survey, Bulletin 20,64 p.

RuitenberG, A.A. 1967. Stratigraphy, structure and metallization, Piskahegan-Rolling Dam area, northern Appalachians, New Brunswick, Canada. Leidse Geologische Mededelingen, 40, pp. 79-120.

Stewart, W.N. 1983. Paleobotany and the evolution of plants. Cambridge University Press, London, 405 p.

Stopes, M.C. 1914. The "Fern Ledges" Carboniferous flora of Saint John, New Brunswick. Geological Survey of Canada, Geological Series, Memoir 41, 38, 142 p.

TAYLOR, T.N. 1981. Paleobotany. An introduction to fossil plant biology. McGraw-Hill, New York, 589 p. 